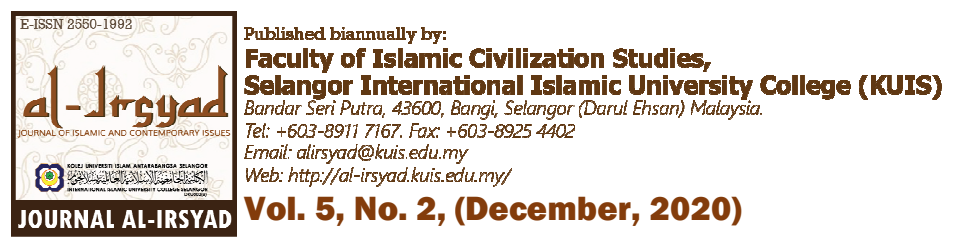

\title{
Faktor luaran dan hubungannya terhadap pencapaian ujian pengesanan dan jantina pelajar dalam kemahiran menulis Bahasa Arab di Institusi Pengajian Tinggi Malaysia
}

\section{[The relationship between external factors on the achievement of assessment tests and gender of students in Arabic writing skills in Malaysian Institutions of Higher Learning]}

\section{Mohamad Rofian Ismail, ${ }^{1 *}$ Ahmad Redzaudin Ghazali, ${ }^{1}$ Khairatul Akmar Abdul Latif, ${ }^{1}$ Fahed Maromar, ${ }^{1}$ \& Saupi Man ${ }^{2}$}

\footnotetext{
${ }^{1}$ Kolej Universiti Islam Antarabangsa Selangor (KUIS)

${ }^{2}$ Universiti Islam Antarabangsa Malaysia (UIAM)
}

\begin{abstract}
* Penulis Penghubung: Dr. Mohamad Rofian bin Ismail. Jabatan Pengajian Bahasa \& Linguistik Arab, Fakulti Pengajian Peradaban Islam, Kolej Universiti Islam Antarabangsa Selangor, 43000, Malaysia, mohdrofian@kuis.edu.my, (+60)13-6777034.
\end{abstract}

\section{Keywords:}

External Factors,

Assessment Tests, Gender, Arabic, Writing Skills

\section{ABSTRACT}

This study was conducted to examine the relationship between external factors on the achievement of assessment tests and gender of students in Arabic writing skills in Malaysian Institutions of Higher Learning. A total of 140 respondents from four Malaysian higher learning institutions (MHLI) were selected, namely Sultan Zainal Abidin University (90 respondents), International Islamic University College of Selangor (25 respondents), Sultan Ahmad Shah Islamic University College, Pahang (9 respondents), and Sultan Ismail Petra International Islamic College (16 respondents) as the study sample. The data obtained were analysed using Statistical Product and Service Solutions (SPSS) version 22.0 software. Inferential analysis method, namely Pearson correlation was used to find the relationship between two different study variables, namely dependent variables and independent variables. The findings showed that there was no significant relationship between external factors on Arabic writing skills based on assessment tests. However, this relationship was found to be significant based on gender of students. This was because the correlation between external factors with student achievement test scores was $(r=-0.062, n=140, p=0.463)$, while the correlation between external factors on gender of students was $(r=0.181, n=$ 140, $p=0.032$ ). This finding indicates that the relationship between external factors with the assessment test was irrelevant in affecting Arabic writing skills, and was not significant. However, the researchers found that external factors can significantly affect the Arabic writing skills among MHLI students based on gender through the analysis of the study obtained.

\section{Kata Kunci:}

Faktor Luaran, Ujian

Pengesanan, Jantina, Bahasa

Arab, Kemahiran Menulis

\section{ABSTRAK}

Kajian ini dijalankan bertujuan untuk mengkaji hubungan antara faktor luaran terhadap pencapaian ujian pengesanan dan jantina pelajar dalam kemahiran menulis bahasa Arab di Institusi Pengajian 


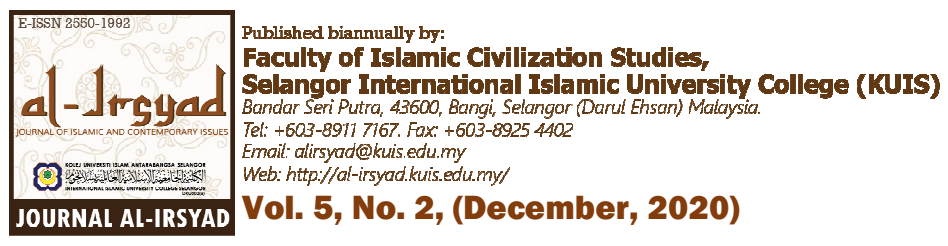

\begin{abstract}
Tinggi Malaysia. Sebanyak 140 orang responden daripada empat buah institusi pengajian tinggi Malaysia (IPTM) dipilih iaitu Universiti Sultan Zainal Abidin (90 orang), Kolej Universiti Islam Antarabangsa Selangor (25 orang), Kolej Universiti Islam Pahang Sultan Ahmad Shah (9 orang), dan Kolej Islam Antarabangsa Sultan Ismail Petra (16 orang) sebagai sampel kajian. Data yang diperolehi dianalisis menggunakan perisian Statistical Product and Service Solutions (SPSS) versi 22.0. Kaedah analisis inferensi iaitu korelasi Pearson digunakan untuk mencari hubungan antara dua pemboleh ubah kajian yang berbeza iaitu pemboleh ubah bersandar dan pemboleh ubah tidak bersandar. Dapatan kajian menunjukkan tidak terdapat hubungan yang signifikan antara faktor luaran terhadap kemahiran menulis bahasa Arab berdasarkan ujian pengesanan namun hubungan ini didapati signifikan berdasarkan jantina pelajar. Hal ini kerana didapati korelasi antara faktor luaran terhadap pencapaian ujian pengesanan pelajar ialah $(\mathrm{r}=-0.062, \mathrm{n}=$ $140, \mathrm{p}=0.463)$, manakala korelasi antara faktor luaran terhadap jantina pelajar ialah $(\mathrm{r}=0.181, \mathrm{n}=140, \mathrm{p}=0.032)$. Dapatan ini menunjukkan hubungan antara faktor luaran terhadap ujian pengesanan adalah tiada kaitan dalam mempengaruhi kemahiran menulis bahasa Arab dan tidak mempunyai signifikan. Namun begitu, pengkaji mendapati faktor luaran boleh mempengaruhi kemahiran menulis bahasa Arab dalam kalangan pelajar IPTM secara signifikan berdasarkan jantina berdasarkan analisis kajian yang diperoleh.
\end{abstract}

\title{
1. Pengenalan
}

Pelajar di institusi pengajian tinggi Malaysia (IPTM) samada lelaki mahupun perempuan merupakan pelajar dewasa yang didedahkan dengan pendekatan pembelajaran andragogi di peringkat pengajian tinggi. Dalam masa yang sama, mereka juga mengambil kelayakan dalam pelbagai disiplin ilmu bagi mengisi pelbagai aspirasi negara termasuklah bidang bahasa Arab. Penguasaan bahasa Arab adalah penting kerana bahasa Arab merupakan bahasa al-Quran dan juga sebagai bahasa sejagat (Sikor et al., 2011).

Persoalan yang ingin dibincangkan di sini ialah apakah punca atau faktor yang menyebabkan kelemahan pencapaian pelajar di peringkat universiti dalam kemahiran menulis bahasa Arab? Adakah faktor luaran merupakan salah satu faktor tersebut? Berdasarkan kajian-kajian lampau, terdapat banyak faktor yang mempengaruhi pembelajaran dan pencapaian pelajar samada di peringkat sekolah menengah mahupun di peringkat IPTM. Faktor-faktor tersebut diklasifikasikan kepada dua kategori iaitu faktor dalaman dan faktor luaran. Kajian berkaitan faktor dalaman adalah yang paling banyak dibincangkan dalam mempengaruhi pencapaian akademik pelajar di peringkat universiti. Antaranya ialah kajian tentang latar belakang seseorang pelajar (Lee \& Nordin, 2006), tahap potensi dan intelek individu (Daud, 2007). Selain itu, faktor konsep kendiri dan motivasi pencapaian (Talib et al., 2014) juga merupakan faktor yang penting mempengaruhi pencapaian akademik pelajar. Menurut Crow dan Crow (1983) tahap pencapaian ujian pengesanan pelajar dalam proses pembelajaran banyak bergantung kepada sikap, minat dan motivasi yang berterusan. Namun begitu, kajian berkaitan faktor luaran dalam mempengaruhi pencapaian akademik pelajar di peringkat IPTM tidak begitu banyak dan menyerlah. Kajian yang sedia ada lebih merujuk kepada pengaruh faktor luaran dalam pencapaian bahasa-bahasa lain terutama bahasa Inggeris, seperti kajian Salleh et al. (2007), Mustaffa et al. (2014) dan Mohd Nor (2015).

Justeru, kurangnya kajian tentang faktor luaran dalam mempengaruhi pencapaian akademik pelajar peringkat universiti di Malaysia khususnya dalam bidang bahasa Arab telah mendorong pengkaji untuk melihat sejauhmana hubungan antara faktor ini terhadap dua pembolehubah yang dikaji iaitu ujian pengesanan kemahiran menulis bahasa Arab dan juga jantina pelajar. 


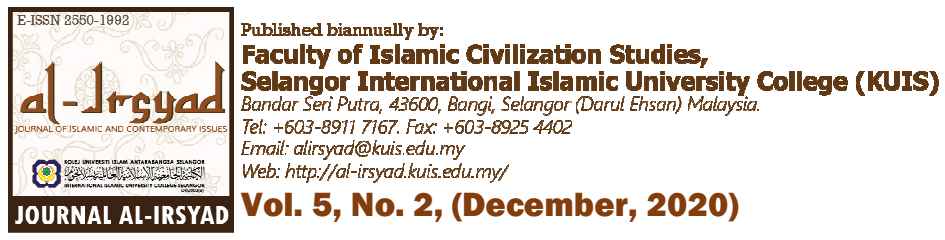

\section{Pengaruh Faktor Luaran dalam Pencapaian Kemahiran Menulis Bahasa Arab Pelajar}

Faktor luaran ialah faktor yang berasal daripada luar diri pelajar yang memberikan rangsangan kepada pelajar untuk menguasai kemahiran menulis bahasa Arab. Faktor luaran dalam kajian ini merujuk kepada subjek bahasa Arab atau buku diploma pusat pengajian tinggi (PPT) di Malaysia dari aspek matlamat, sukatan, kaedah, penilaian dan faktor persekitaran pelajar (Ismail et al., 2020).

Terdapat beberapa faktor luaran yang mempengaruhi kelemahan pelajar dalam penulisan bahasa Arab seperti pengaruh persekitaran bahasa Arab yang kurang menyokong. Pelajar kurang didedahkan dengan suasana dan persekitaran bahasa Arab dalam aktiviti pembelajaran harian mereka. Dalam kajian Nik Mohd Rahimi (1999), hanya 5\% pelajar menggunakan bahasa Arab sebagai bahasa komunikasi dengan guru bahasa Arab mereka dan hanya $1.7 \%$ sahaja pelajar bertutur menggunakan bahasa Arab sesama mereka. Kajian ini menunjukkan persekitaran bahasa Arab dalam kalangan pelajar kurang memberangsangkan. Faktor persekitaran mendatangkan kesan dalam penguasaan bahasa Arab dalam diri pelajar (Kouraogo, 2010).

Faktor lain yang mempengaruhi kelemahan pelajar dalam kemahiran menulis ialah penggunaan buku teks atau modul untuk subjek kemahiran menulis yang mempunyai kesilapan bahasa khususnya kesilapan berkaitan Nahu dan sorof samada disedari atau sebaliknya dalam kalangan guru. Buku teks merupakan bahan pengajaran dan pembelajaran yang paling dominan dan sering digunakan sebagai sumber pemerolehan ilmu sejak sistem pendidikan formal bahasa Arab dijalankan di sekolah (Ismail \& Othman, 2012). Tenaga pengajar menggunakan buku teks sebagai panduan dan sukatan tajuk yang perlu diajar kepada pelajar manakala pelajar pula, buku teks dijadikan bahan bacaan bagi sesuatu pelajaran. Justeru, kesalahan dan kesilapan bahasa khususnya yang berkaitan dengan ilmu Nahu dan Sorof di dalam buku teks sedikit sebanyak akan mengelirukan pelajar dan memberi kesan yang negatif dalam kemahiran menulis. Buku teks sepatutnya menggunakan bahasa yang betul lebih-lebih lagi buku teks bahasa Arab agar pengajaran kemahiran menulis yang disampaikan di dalam kelas betul dan tepat (Ghani, 2011).

Faktor seterusnya adalah kaedah yang digunakan oleh pensyarah dalam proses pengajaran kemahiran menulis. Pengajaran pensyarah kurang memberi pendedahan tentang kemahiran, teknik dan strategi menulis dalam kelas menyebabkan pelajar kurang bersedia untuk menulis. Pernyataan kelemahan pengajaran guru dinyatakan oleh Baki (2003) iaitu kebanyakan guru pada umumnya masih kurang jelas tentang kandungan ilmu penulisan dan mereka menerapkan pengalaman yang dialami ketika mempelajari penulisan di sekolah dahulu sebagai asas mengajar penulisan kepada pelajar. Kekurangan masa untuk pelaksanaan aktiviti dan pensyarah tidak berkesempatan memberi bimbingan yang wajar juga antara faktor yang menyumbang kelemahan pelajar dalam penulisan Arab. Dapatan ini lebih kurang sama dengan dapatan Noh et al. (2018) iaitu permasalahan yang berlaku adalah disebabkan persekolahan yang mengamalkan kurikulum yang kompleks, tidak prihatin kepada perbezaan keupayaan murid menyebabkan guru terikat dalam menghabiskan sukatan pelajaran.

Pengkaji juga mendapati bahawa punca sesuatu kesilapan yang berlaku tidak terhad kepada satu atau dua faktor sahaja, tetapi boleh disebabkan oleh beberapa faktor lain. Antara lain ialah keberkesanan matlamat dan sukatan atau modul pendidikan serta penilaian terhadap subjek.

\subsection{Faktor Matlamat}

Matlamat adalah menyampaikan sesuatu kepada pelajar yang bertujuan agar pelajar mencapai apa yang dirancangkan selepas tamat pengajian dalam tempoh tertentu (Nawi et al., 2014). Manakala Tui'mah (1989) sebelum itu menjelaskan bahawa tujuan atau matlamat pengajian adalah untuk memperbaiki peribadi (السلوك) pelajar melalui pengalaman yang didapatinya sepanjang tempoh pengajian.

Menurut Ab Latif et al. (2015) bahawa matlamat reka bentuk kurikulum mesti menekankan dua aspek. Aspek tersebut iaitu logik (logical methods) dan metodologi empirik (empirical methods). Metodologi logik merangkumi tiga perkara iaitu kesesuaian, keberkesanan dan kesepakatan matlamat reka bentuk dengan aspek kemasyarakatan dan undang-undang. Manakala metodologi empirik pula merangkumi empat perkara. Empatempat perkara tersebut iaitu matlamat reka bentuk mesti memenuhi matlamat kumpulan yang disasarkan, diterima oleh pakar pendidik dan masyarakat, mesti diuji keberkesanannya pada khalayak ramai serta mempunyai kesinambungan yang berterusan.

Ab Latif et al. (2015) dalam kajiannya menyatakan matlamat reka bentuk silibus bahasa Arab terbahagi kepada dua bahagian iaitu matlamat umum dan matlamat khusus. Matlamat umum tidak dapat dicapai melalui mata pelajaran tertentu sahaja. Matlamat tersebut dapat dicapai selepas selesai mempelajari kesemua atau sebahagian besar dari kurikulum yang dirancang. Matlamat umum juga dikenali sebagai matlamat masa panjang. Ia meliputi kebaikan yang didapati oleh individu dan masyarakat. Menurut Mat (2010) matlamat umum juga 


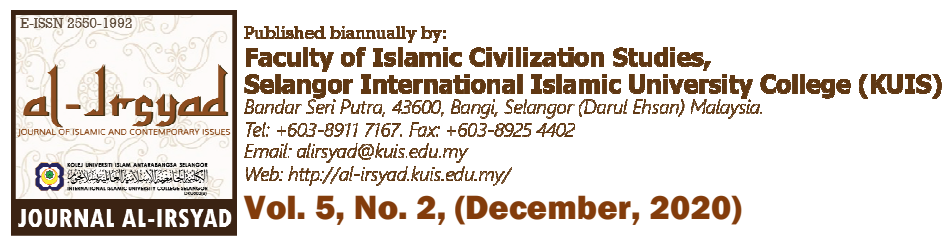

meliputi matlamat umum pengajian yang digariskan oleh kerajaan. Hal ini dijalankan dalam usaha untuk memajukan, memperbaiki kehidupan dan meningkatkan tahap intelektual masyarakat.

Matlamat khusus ditumpukan dalam merealisasikan matlamat yang ingin dicapai dalam subjek tertentu dalam bahasa Arab. Matlamat ini biasanya dikenali sebagai matlamat peribadi (الهدف السلوكى) yang diperoleh pelajar selepas tamat tempoh pengajian (Nasohah et al., 2015). Hasil yang diperoleh dalam matlamat khusus lebih tertumpu kepada perubahan pelajar dari segi keperibadian, tingkah laku, peningkatan kemahiran dan kemampuan menguasai beberapa kemahiran berbahasa Arab dengan baik. Perbezaan ini dapat dilihat pada pelajar sama ada semasa proses pembelajaran sesuatu mata pelajaran berlaku atau selepas proses pembelajaran itu berakhir (Arbaa \& Ahmad, 2017).

Dalam pengajaran kemahiran menulis, setiap guru perlu merancang dengan teliti matlamat pengajaran yang ingin dicapai. Perancangan tersebut termasuklah dari sudut pemilihan kaedah pengajaran yang berkesan dan serasi dengan ciri-ciri kemahiran menulis, aktiviti pengajaran yang sesuai dan penggunaan alat bantu mengajar yang bertepatan dengan kaedah pengajaran yang digunapakai. Hal ini kerana menurut Othman et al. (2011) keberkesanan kaedah pengajaran dapat merealisasikan matlamat yang dirancang sehingga menghasilkan pelajar yang faham, mahir dan mampu menyerap ilmu pengetahuan dan kemahiran yang diajar oleh guru. Sebelum itu Baba (2009) menyatakan keberkesanan kaedah pengajaran juga dikaitkan dengan pencapaian matlamat yang dirancang melalui kaedah pengajaran yang dilaksanakan. Pencapaian matlamat pengajian melalui sukatan yang dirancang adalah dua unsur penting dalam mengukur kefahaman pelajar. Tindak balas pelajar semasa atau selepas sesi pengajian menjadi kayu ukur tahap kefahaman mereka terhadap sukatan yang dibentuk. Ia juga menjadi kayu ukur kejayaan dalam mencapai matlamat yang dirancang.

\subsection{Faktor Kurikulum/Silibus/Modul}

Menurut kajian yang telah dibuat oleh Ismail et al. (2016) mendapati modul kemahiran menulis bahasa Arab bagi peringkat pengajian tinggi di Malaysia tidak mencukupi selain kurang memberi penekanan dari sudut psikologi pelajar. Kajian ini disokong oleh kajian Mohamad dan Jabar (2017) yang mendapati bahawa kesalahan pelajar Melayu dalam penguasaan penulisan bahasa Arab berpunca daripada faktor kelemahan kurikulum dan strategi pembelajaran yang kurang berkesan. Proses pembelajaran bahasa Arab pada peringkat pengajian tinggi memerlukan modul pembelajaran berdasarkan kaedah dan gaya penulisan yang sesuai bagi memudahkan pelajar berlatih menulis. Pelajar perlu dilatih menulis dengan baik berpandukan modul yang disediakan serta bersesuaian dengan tahap kebolehan mereka. Hal ini kerana kurikulum pembelajaran menitik beratkan bahan pengajaran (Aisyah et al., 2017). Modul dan latihan bahasa Arab yang berkualiti mampu meningkatkan penguasaan pelajar dalam kemahiran menulis bahasa Arab dengan baik khususnya penulisan karangan. Modul kemahiran menulis bahasa Arab pada peringkat pengajian tinggi Malaysia masih terhad dan perlu diperbanyak (Ismail et al., 2016; Samah, 2012) selain mengambil kira aspek psikologi pelajar yang berbeza. Modul yang sesuai, mesra pelajar, bercirikan pembelajaran kendiri dan mengambil kira keperluan pelajar akan mampu membangkitkan motivasi dalam menulis bahasa Arab. Modul yang mengambil pendekatan proses dalam pembelajaran mengarang juga perlu diberikan tumpuan (Rejab, 2016) berbanding dengan tumpuan terhadap hasil mengarang. Proses mengarang itu sifatnya rekursif atau berulang-ulang yang bermula dengan tahap perancangan, penyediaan draf karangan, penyemakan dan penulisan semula sehingga akhirnya dapat menghasilkan sebuah karangan yang berkualiti. Penglibatan pelajar secara aktif penting dalam setiap aktiviti.

\subsection{Faktor Kaedah Pengajaran}

Kaedah pengajaran merupakan cara atau perancangan yang diatur oleh guru sebelum memasuki kelas dan dilaksanakannya semasa sesi pengajaran (Mustari et al., 2012). Pendapat Ini disokong oleh Ratnam (2017) yang mengatakan kaedah pengajaran adalah meliputi empat perkara. Perkara pertama iaitu digunakan oleh guru semasa sesi pembelajaran berlaku. Perkara lainnya iaitu bertujuan untuk merealisasikan matlamat yang dibentuk, melalui cara yang mudah difahami dan dalam lingkungan masa yang singkat.

Terdapat tiga faktor yang menjadi keutamaan para guru dalam menyampaikan pengajaran. Faktor pertama iaitu dengan memberi perhatian kepada kumpulan sasaran (بحتمع اللغة). Faktor kedua dan ketiga iaitu tahap pelajar (مستوى الدارسين) dan tahap penguasaan mereka dalam bahasa Arab (مستوى اللغة) (Tu'imah, 1989). Memberi perhatian kepada kumpulan sasaran bermaksud peka dengan keadaan kumpulan sasaran. Pemerhatian tersebut merangkumi demografi dan latarbelakang pelajar iaitu pelajar yang terdiri daripada kumpulan yang berbeza dari sudut sosio ekonomi dan tahap penguasaan bahasa Arab. 


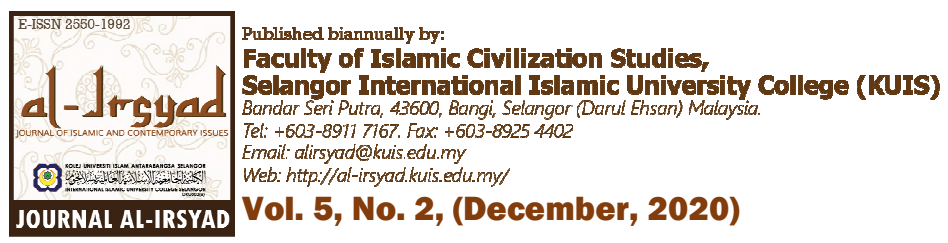

Samah (2007) menyatakan antara ciri-ciri pengajaran yang berkesan ialah pengajaran berpusat kepada pelajar, penggunaan pelbagai kaedah dan teknik pengajaran. Pendapat ini disokong oleh Mamat dan Ismail (2010). Beliau menyatakan bahawa pensyarah hendaklah mempunyai pelbagai kaedah dan teknik pengajaran yang boleh digunakan dalam situasi yang berbeza dan pelajar yang berbeza.

\subsection{Faktor Penilaian Subjek}

Penilaian subjek bertujuan memastikan sejauh mana matlamat pembelajaran yang dirancang telah tercapai. Ini selaras dengan Waty (2017) menyatakan bahawa tujuan penilaian pada asasnya iaitu menjalankan tindakan susulan selepas mendapat keputusan yang dikehendaki.

Wulansari (2015) pula berpendapat penilaian mesti berbentuk ilmiah. Segala hasil yang diperoleh mesti dicatat dan direkodkan. Ia bertujuan sebagai rujukan yang amat penting dalam penilaian semula dan sebagai rujukan perbandingan bagi keputusan-keputusan baru yang diperoleh. Menurut Daud (2015), penilaian silibus hendaklah berpanjangan. Ini bermaksud, penilaian tersebut tidak hanya terhenti selepas mendapat satu keputusan yang diingini sahaja dalam masa yang singkat. Matlamat yang paling penting dalam penilaian kurikulum adalah kesinambungan silibus yang dirancang pada masa datang.

Perkara asas hasil penilaian silibus ialah memperbaiki silibus ke arah yang lebih baik. Walau bagaimanapun, terdapat beberapa kepentingan penilaian silibus bahasa Arab seperti yang dinyatakan oleh Ismail et al. (2011). Antaranya menentukan tahap penguasaan pelajar dalam bahasa Arab, membantu mereka dalam memilih program bersesuaian dan berkemampuan bahasa dan membantu serta menggalakkan mereka dalam mempertingkatkan kemahiran berbahasa. Manakala Bakar et al. (2012) menyatakan bahawa kepentingan penilaian silibus adalah untuk mendedahkan aspek kelemahan pelajar dengan cara yang praktikal.

\subsection{Faktor Persekitaran}

Faktor persekitaran (البيئة المصاحبة) juga turut memainkan peranan penting dalam pemilihan kaedah pengajaran yang berkesan (As-Shahatah, 1993). Mengutamakan matlamat pengajian bahasa bermaksud menjaga dan menyusun kaedah pengajaran yang diguna pakai dalam masa yang terbatas. Ini bertujuan agar ia tidak tersasar dari matlamat kurikulum yang sebenar. Di samping itu, penggunaan alat bantu mengajar amat penting semasa pelaksanaan sesi pengajaran berlaku. Ia dapat membantu mempertingkatkan kefahaman pelajar dalam memahami sukatan mata pelajaran yang dipelajari. Faktor-faktor tersebut memberi impak yang besar dalam menentukan kaedah pengajaran yang berkesan untuk pengajaran penulisan bahasa Arab kepada pelajar IPT.

Semua faktor-faktor luaran yang dinyatakan ini umumnya memberi impak yang positif kepada pelajar khususnya pelajar peringkat pengajian tinggi seperti universiti dan kolej di Malaysia dalam sistem pengajaran dan pembelajaran kemahiran menulis bahasa Arab seterusnya meningkatkan pencapaian pelajar. Namun begitu, terdapat kajian-kajian lepas menunjukkan ramai dalam kalangan pelajar peringkat universiti tidak mampu menulis ayat bahasa Arab dengan baik (Samah, 2012), lemah dalam kemahiran imla' (Baharum \& Samah, 2015), lemah dalam penggunaan damīr sama ada dalam penulisan dan terjemahan teks (Abdullah, 2017) kurang mampu membina perenggan karangan khususnya dari sudut kohesi dan koheren serta tidak dapat menyempurnakan tugasan kemahiran menulis seperti menulis laporan dan menulis berita dengan baik di rumah (Ismail et al., 2018). Kesimpulannya, pengkaji melihat kelemahan-kelemahan ini berpunca daripada faktorfaktor luaran yang tidak dikawal dengan sebaik-baiknya. Sepatutnya, setiap pihak berkepentingan seperti pihak kementerian pendidikan, pihak institusi pengajian tinggi dan pihak sekolah memandang serius perkara ini dengan membuat pemantauan secara berterusan dan memastikan matlamat pengajaran kemahiran menulis, silibus pembelajaran, kaedah pengajaran, penilaian subjek dan juga persekitaran pelajar memainkan peranan masing-masing seterusnya menepati keperluan dan kesesuaian pelajar sebagaimana yang telah dinyatakan dalam kajian (Ismail et al., 2020).

\section{Metodologi Kajian}

Kajian ini merupakan kajian berbentuk kuantitatif pada tahap inferensi. Sebanyak 140 orang responden dipilih sebagai sampel kajian daripada empat buah institusi pengajian tinggi Malaysia (IPTM) iaitu Universiti Sultan Zainal Abidin (90 orang), Kolej Universiti Islam Antarabangsa Selangor (25 orang), Kolej Universiti Islam Pahang Sultan Ahmad Shah (9 orang), dan Kolej Islam Antarabangsa Sultan Ismail Petra (16 orang) sebagai sample kajian. Jumlah sampel yang diperolehi adalah melalui teknik persampelan berstrata yang digunakan iaitu sampel yang diambil daripada populasi pelajar peringkat diploma bahasa Arab yang sedang mempelajari subjek 


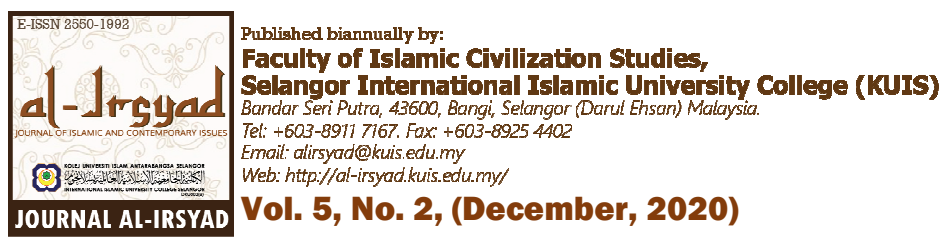

kemahiran menulis bahasa Arab di IPTM. Justifikasi jumlah sampel yang diperoleh sebanyak 140 responden adalah disebabkan kurangnya populasi pelajar diploma bahasa Arab yang terlibat berdasarkan batasan kajian ini terutama di institusi pengajian tinggi swasta (IPTS) berbanding dengan populasi pelajar diploma bahasa Arab di IPTA. Selain itu, hanya UniSZA satu-satunya IPTA yang betul-betul kukuh (established) dalam menawarkan program diploma bahasa Arab di Malaysia. Data yang diperolehi dianalisis menggunakan perisian Statistical Product and Service Solutions (SPSS) versi 22.0. Satu set soal selidik mengandungi latar belakang responden, domain faktor luaran dan ujian pengesanan kemahiran menulis bahasa Arab digunakan sebagai instrumen kajian dan diagihkan kepada responden kajian. Data-data yang dianalisis ini seterusnya dibentangkan menggunakan kaedah analisis inferensi berpandukan Korelasi Pearson. Analisis kajian yang dibuat adalah bertujuan untuk menguji dan mendapatkan jawapan bagi dua hipotesis nol yang dibentuk seperti berikut:

i. H01 Tidak terdapat hubungan yang signifikan antara faktor luaran terhadap pencapaian ujian pengesanan pelajar.

ii. H02 Tidak terdapat hubungan yang signifikan antara faktor luaran terhadap kemahiran menulis bahasa Arab berdasarkan jantina.

\section{Perbincangan Dapatan Kajian}

Perbincangan dapatan adalah merujuk kepada keputusan hipotesis-hipotesis nol yang telah dibentuk di awal permulaan kajian. Hasil kajian dibentangkan berdasarkan statistik yang diperoleh. Dapatan yang diperoleh daripada analisis akan menjawab persoalan sama ada hipotesis nol yang telah dibentuk diterima atau ditolak setelah diuji. Berikut dinyatakan hasil keputusan hipotesis nol yang diperoleh:

\subsection{H01: Tidak terdapat hubungan yang signifikan antara faktor luaran terhadap pencapaian ujian pengesanan pelajar.}

Jadual 1 menunjukkan dapatan yang diperolehi:

Jadual 1. Korelasi antara faktor luaran terhadap pencapaian ujian pengesanan pelajar

\begin{tabular}{|c|c|c|c|}
\hline & & Faktor luaran & $\begin{array}{l}\text { Ujian Pengesanan Kemahiran } \\
\text { Menulis Bahasa Arab }\end{array}$ \\
\hline \multirow[t]{4}{*}{ Faktor luaran } & Korelasi & 1 & -0.062 \\
\hline & Pearson & & \\
\hline & Sig. (2-tailed) & & 0.463 \\
\hline & $\mathrm{N}$ & 140 & 140 \\
\hline \multirow{4}{*}{$\begin{array}{l}\text { Ujian Pengesanan Kemahiran } \\
\text { Menulis Bahasa Arab }\end{array}$} & Korelasi & -0.062 & 1 \\
\hline & Pearson & & \\
\hline & Sig. (2-tailed) & 0.463 & \\
\hline & $\mathrm{N}$ & 140 & 140 \\
\hline
\end{tabular}

Jadual 1 di atas menunjukkan hubungan korelasi antara faktor luaran terhadap pencapaian ujian pengesanan pelajar dalam kemahiran menulis bahasa Arab. Korelasi yang diperoleh antara faktor luaran terhadap pencapaian ujian pengesanan pelajar ialah $(\mathrm{r}=-0.062, \mathrm{n}=140, \mathrm{p}=0.463)$. Analisis kajian menunjukkan terdapat hubungan linear yang negatif sangat lemah $(\mathrm{r}=-0.062)$ yang tidak signifikan $(\mathrm{p}=0.463)$ di antara faktor luaran terhadap ujian pengesanan pelajar. Dapatan ini selari dengan kajian Ismail dan Othman (2012) dengan menyatakan bahawa faktor luaran bukan sebab utama kelemahan pelajar dalam kemahiran menulis bahasa Arab. Hal ini kerana faktor modul dan persekitaran sebagai contoh mempunyai kekuatan dan kelemahan yang tersendiri. Jadual 2 pula merumuskan dapatan yang diperolehi dalam menjawab persoalan H01 yang dikaji: 


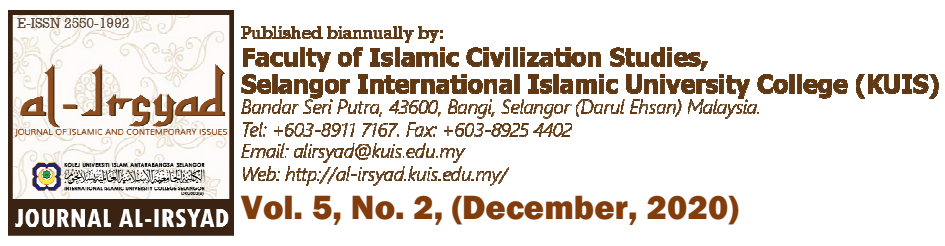

Jadual 2. Faktor luaran terhadap ujian pengesanan kemahiran menulis Bahasa Arab

\begin{tabular}{cccc}
\hline Faktor & Nilai Korelasi r & Aras Signifikan p & Status H0 \\
\hline Faktor luaran & -0.062 & 0.463 & Diterima \\
\hline
\end{tabular}

Jadual 2 di atas menunjukkan tidak terdapat perbezaan signifikan antara faktor luaran terhadap ujian pengesanan kemahiran menulis bahasa Arab dengan nilai $r=-0.062$ dan $p=0.463$. Justeru, dapat dirumuskan bahawa status $\mathrm{H} 0$ yang telah dibentuk adalah gagal ditolak bahkan diterima kerana menepati pada persoalan H01. Hal ini bermaksud hubungan antara faktor luaran terhadap ujian pengesanan adalah tiada kaitan dalam mempengaruhi kemahiran menulis bahasa Arab dan tidak mempunyai signifikan. Hal ini berkemungkinan berlaku disebabkan persekitaran bahasa Arab yang tidak dipraktikkan secara berterusan di Malaysia sekaligus tidak membantu pelajar menguasai bahasa Arab dengan baik (Mat, 2010).

\subsection{H02: Tidak terdapat hubungan yang signifikan antara faktor luaran terhadap kemahiran menulis bahasa Arab berdasarkan jantina.}

Jadual 3 menunjukkan dapatan yang diperolehi:

Jadual 3. Korelasi antara faktor luaran terhadap kemahiran menulis Bahasa Arab berdasarkan jantina

\begin{tabular}{llll}
\hline & & Jantina & Faktor Luaran \\
\hline Jantina & Korelasi Pearson & 1 & $.181^{*}$ \\
& Sig. (2-tailed) & & .032 \\
& N & 140 & 140 \\
& Koktor Luaran & $.181^{*}$ & 1 \\
& Sig. (2-tailed) & .032 & 140 \\
\hline
\end{tabular}

Jadual 3 menunjukkan korelasi yang diperoleh antara faktor luaran terhadap kemahiran menulis bahasa Arab berdasarkan jantina ialah $(\mathrm{r}=0.181, \mathrm{n}=140, \mathrm{p}=0.32)$. Analisis kajian menunjukkan terdapat hubungan linear positif sangat lemah $(r=0.181)$ yang signifikan $(\mathrm{p}=0.032)$ di antara faktor luaran terhadap kemahiran menulis bahasa Arab berdasarkan jantina. Menurut Mat Teh et al. (2008) jantina pelajar memainkan peranan yang besar dalam pencapaian kemahiran bahasa Arab pelajar. Pelajar perempuan didapati mendominasi semua aspek pencapaian bahasa Arab. Namun begitu, pelajar lelaki didapati kurang berlaku persaingan sesama mereka. Jadual 4 pula merumuskan dapatan yang diperolehi dalam menjawab persoalan H02 yang dikaji:

Jadual 4. Faktor luaran berdasarkan jantina

\begin{tabular}{cccc}
\hline Faktor & Nilai Korelasi r & Aras Signifikan p & Status Ho \\
\hline Faktor Luaran & 0.181 & 0.032 & Ditolak \\
\hline
\end{tabular}

Jadual 4 di atas menunjukkan terdapat signifikan di antara faktor luaran berdasarkan jantina dengan nilai $r=0.181$ dan $p=0.032$. Ini menunjukan bahawa status $\mathrm{H} 02$ yang telah dibentuk berjaya ditolak sekaligus menunjukkan faktor luaran pelajar mempengaruhi kemahiran menulis bahasa Arab mereka berdasarkan jantina. Walaupun begitu, hubungan linear yang diperoleh adalah positif yang sangat lemah. Dapatan ini selari dengan kajian Mat Teh et al. (2008), Islam (2015), dan Pisal dan Teh (2018).

\section{Penutup}

Kajian ini merumuskan bahawa faktor luaran tidak secara signifikan mempengaruhi kemahiran penulisan bahasa Arab pelajar di IPTM. Hal ini bermaksud, kelemahan dan kecemerlangan pelajar di IPTM tiada kaitan dan tidak dipengaruhi oleh faktor luaran seperti matlamat pengajaran dan pembelajaran, persekitaran, modul, kaedah pengajaran dan guru. Namun begitu, pengkaji berpandangan optimis bahawa faktor luaran mempunyai hubungan yang kuat dalam mempengaruhi pencapaian pelajar berdasarkan jantina di peringkat pengajian tinggi dalam kemahiran menulis bahasa Arab. Hal ini bermaksud, jantina pelajar berpotensi sebagai penentu kepada pencapaian pelajar IPTM dalam kemahiran menulis bahasa Arab. Kesimpulannya, walaupun faktor luaran tidak memainkan peranan penting dalam mempengaruhi pencapaian kemahiran menulis bahasa Arab pelajar, namun pengkaji merasakan sumbangan faktor ini dalam proses pengajaran dan pembelajaran pelajar di peringkat 


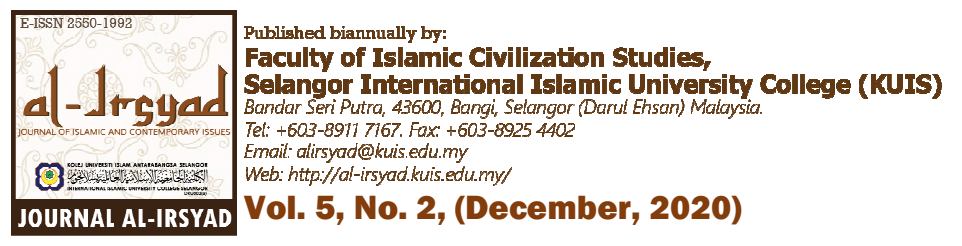

universiti telah sedikit sebanyak mencorak perubahan yang positif dalam kemenjadian pelajar dan keberhasilan mereka dalam pengajian bahasa Arab peringkat diploma dan sarjana muda.

\section{Rujukan}

Abdullah, N. (2017). أسباب الضـعف في مـدى مقروئيـة النصـوص القرآنيـة المترجمـة إلى اللغـة الملايويـة. Al-Irsyad: Journal of Islamic and Contemporary Issues, 2(2), 73-82.

Ab Latif, K. A., Ghazali, A. R., \& Ismail, M. R. (2015). Pengaruh objektif kurikulum terhadap penguasaan kemahiran bahasa Arab dalam kalangan pelajar Program Sarjana Muda Bahasa Arab (PSMBA) di Institusi Pengajian Tinggi Awam (IPTA) Malaysia. E-Journal of Arabic Studies \& Islamic Civilization, Volume 2, 90-100.

Arbaa, R., Jamil, H., \& Ahmad, M. Z. (2017). Model bersepadu penerapan kemahiran abad ke-21 dalam pengajaran dan pembelajaran. Jurnal Pendidikan Malaysia, 42(1), 1-11.

Baba, I. (2009). Keberkesanan pengajaran dan pembelajaran dan kaitannya terhadap prestasi akademik pelajar UTHM (Doctoral dissertation, Universiti Tun Hussein Onn Malaysia).

Baki, R. (2003). Pengajaran dan pembelajaran bahasa Melayu. Shah Alam, Malaysia: Karisma Publications Sdn. Bhd.

Baharum, A. S., \& Samah, R. (2015). Persepsi pelajar universiti awam terhadap kesalahan bahasa Arab, faktor penyumbang dan implikasi. Sains Humanika, 6(1).

Bakar, M. A. A., Said, S. N. M., Sabil, S., Ibrahim, N. H., Roose, A. R. M., Aden, E., ... \& Marawi, Z. H. (2012). Pemantapan pengajaran dan pembelajaran kursus Tamadun Islam dan Tamadun Asia (TITAS): kajian tinjauan persepsi pelajar. Regional Conference on Cross Cultural Communication and National Integration, 19-21.

Crow, L. D. \& Crow, A. (1983). Psikologi pendidikan untuk perguruan. Kuala Lumpur: Dewan Bahasa dan Pustaka.

Daud, W. M. W. (2007). Persepsi pelajar terhadap pengajaran dan pembelajaran sains dan matematik dalam Bahasa Inggeris di tiga buah Sekolah Menengah Kebangsaan di Pasir Puteh, Kelantan (Doctoral dissertation, Universiti Teknologi Malaysia).

Daud, Z. (2015). Penilaian pelaksanaan kurikulum qiraat di Darul Quran dan ma'ahad tahfiz al-Qur'an di Malaysia (Doctoral dissertation, University of Malaya).

Ghani, K. A. (2011). Kebolehbacaan buku teks bahasa Arab tinggi berasaskan ujian kloz dalam kalangan pelajar di SMKA. GEMA Online ${ }^{\circledR}$ Journal of Language Studies, 11(2).

Islam, A. M. S. (2015). Faktor demotivasi pembelajaran bahasa Arab dalam perspektif siswa Madrasah. Arabiyât: Jurnal Pendidikan Bahasa Arab dan Kebahasaaraban, 2(1), 1-16.

Ismail, M. F., \& Othman, M. S. (2012). Faktor-faktor yang mempengaruhi pencapaian pelajar dalam pengajaran \& pembelajaran bahasa Arab: Satu tinjauan di SMAP Kajang. Bangi: Universiti Kebangsaan Malaysia.

Ismail, Z., Tamuri, A. H., Yusoff, N. M. R. N., \& Othman, M. A. U. (2011). Teknik pengajaran kemahiran bertutur bahasa arab di SMKA di Malaysia. GEMA Online ${ }^{\circledR}$ Journal of Language Studies, 11(2).

Ismail, M. R., Ghazali, A. R., Latif, K. A. A., \& Daoh, M. (2018). Kebolehan pelajar Sarjana Muda Bahasa Arab di Universiti Awam Malaysia dalam kemahiran menulis karangan bahasa Arab. Selangor Humaniora Review, 2(1), 9-21.

Ismail, M. R., Ghazali, A. R., Latif, K. A. A., \& Daoh, M. (2016). Kerangka pembinaan modul kemahiran menulis karangan bahasa Arab untuk penutur bukan Arab di IPTA Malaysia. Seminar Antarabangsa Akidah, Dakwah dan Syariah 2016 (IRSYAD 2016). Bangi, Selangor: Kolej Universiti Islam Antarabangsa Selangor. 581-592.

Ismail, M. R., Ghazali, A. R., Latif, K. A. A., Maromar, F., \& Man, S. (2020). Hubungan antara faktor dalaman dan faktor luaran dalam mempengaruhi kemahiran menulis bahasa Arab Pelajar di Institusi Pengajian Tinggi Malaysia. e-Jurnal Bahasa dan Linguistik (e-JBL), 2(1), 1-12.

Kouraogo, P. (2010). Policy measures to improve the quality of education in Burkina Faso. Africa-Asia Experience Sharing Seminar in Ghana Efforts towards Improving the Quality of Education. Accra, Ghana.

Lee, S. S., \& Nordin, A. (2006). Kajian mengenai pelajar pencapaian tinggi dan pelajar pencapaian sederhana dalam penyelesaian masalah sains dalam bahasa Inggeris dan bahasa Melayu (Doctoral dissertation, Universiti Teknologi Malaysia). 


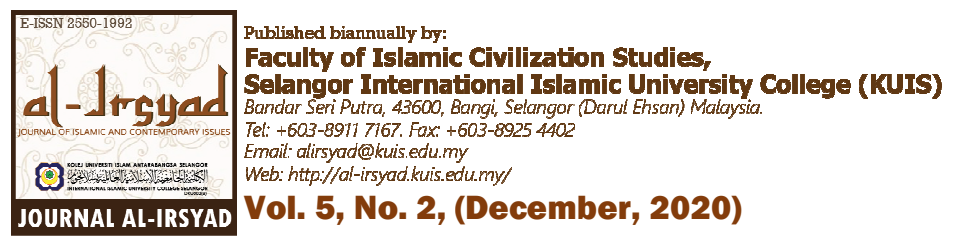

Mamat, A., \& Ismail, S. (2010). Kaedah pengajaran dan pembelajaran guru pemulihan Jawi di Malaysia. Proceedings of the 4th International Conference on Teacher Education: Join Conference UPI \& UPSI (pp. 321-329).

Mat, A. C. (2010). Situasi pembelajaran bahasa asing di institut pengajian tinggi: Perbandingan antara bahasa Arab, bahasa Mandarin dan bahasa Perancis. Asean Journal of Teaching and Learning in Higher Education (AJTLHE), 2(2), 9-20.

Mohamad, A. H. \& Jabar, M. A. A. (2017). Faktor kesalahan bahasa yang mempengaruhi pelajar Melayu dalam mempelajari bahasa Arab. Jurnal AL-ANWAR, Persatuan Bekas Mahasiswa Islam Timur (PBMITT). Volume 1 (3); 21-32

Mohd Nor, M. (2015). Hubungan sikap dan motivasi dengan Pencapaian bahasa Inggeris murid Sekolah Kebangsaan Felda Daerah Bera (Doctoral dissertation, Universiti Pendidikan Sultan Idris).

Mustaffa, S. R., Ariffin, R. M. R., \& Said, N. S. (2014). Kekeliruan jati diri punca bahasa bercampur aduk. Jurnal Bahas, 14(1), 134-158.

Mustari, M. I., Jasmi, K. A., Muhammad, A., Yahya, R., Mustari, M. I., Jasmi, K. A., ... \& Yahya, R. (2012). Model pengajaran dan pembelajaran bahasa Arab. In Seminar Antarabangsa Pengurusan \& Pendidikan Islam (SEA PPI2012), Le Grandeur Palm Resort, Johor Bahru (pp. 8-9).

Nasohah, U. N., Gani, M. I. B. A., Shaid, N. B. M., \& Shaid, M. (2015). Model ADDIE dalam proses reka bentuk modul pengajaran: bahasa Arab tujuan khas di Universiti Sains Islam Malaysia sebagai contoh. Proceedings of the International Seminar on Language Teaching, 4-5.

Nawi, N. H. M., Yusuff, N. A., Yaacob, M. B. C., \& Salleh, N. H. (2014). Matlamat dan halatuju sistem pengajian tahfiz di Kelantan: satu pengamatan awal. Dlm. 4th International Conference and Exhibition on Islamic Education (ICIEd 2014), Kota Bharu, 1-15.

Noh, M. A. M., Pisol, M. I. M., Ilias, M. F., Sulaiman, M. S., \& Fauzi, M. S. H. M. (2018). Pelaksanaan strategi pelajar sebelum mempraktikkan kemahiran menulis tugasan akademik (the strategies of implementing pre-academic writing assignment skills). e-Bangi, 15(5).

Othman, A. J., Normarini, N., Darusalam, G., \& Siraj, S. (2011). Cabaran guru program LINUS dalam pengajaran dan pembelajaran bahasa. Issues in Education, 34, 37-51.

Pisal, N. A., \& Teh, K. S. M. (2018). Perbezaan jantina dalam penggunaan strategi pembelajaran kemahiran berbahasa Arab [Gender differences in the use of strategies for Arabic language learning]. Journal of Nusantara Studies (JONUS), 3(1), 143-153.

Ratnam, K. (2017). Kesan teknik eksplorasi internet berasaskan pendekatan konstruktivisme terhadap penulisan karangan fakta (Doctoral dissertation, Universiti Pendidikan Sultan Idris).

Rejab, H. M. (2016). Amalan pentaksiran dalam pengajaran dan pembelajaran Insya' Sijil Tinggi Agama Malaysia (STAM). Tesis Doktor Falsafah. Fakulti Pendidikan. Kuala Lumpur: Universiti Malaya.

Salleh, M. S., \& bin Amir Razli, M. Z. F (2006). Faktor-faktor mempengaruhi pencapaian akademik yang rendah di kalangan mahasiswa/i Universiti Teknologi MARA (UiTM) Kelantan bagi Semester Disember 2005-Mei 2006. Dlm. National Student Development Conference (NASDEC) 2006, Kuala Lumpur, 1-13.

Samah, R. (2012). Pembinaan ayat bahasa Arab dalam kalangan lepasan Sekolah Menengah Agama. GEMA Online ${ }^{\circledR}$ Journal of Language Studies, 12(2).

Samah, R. (2007). Penggunaan internet dalam pengajaran bahasa: Kajian terhadap bahasa Arab komunikasi pelancongan. Malaysian Education Dean's Council Journal, 1(2), 83-95.

Sikor, A., Ibrahim, S., Mohd Hashim, M. H., Madar, A. R., \& Zamani, N. A. (2011). Teknik pembelajaran andragogi dalam kalangan pelajar dewasa di Institusi Pengajian Tinggi Awam Kementerian Pengajian Tinggi Malaysia. (Project Report, Universiti Tun Hussein Onn Malaysia).

Sjahrony, A, Lubis, M. A, Baharudin, H. \& Kamis M. S. (2017). Kepentingan pembelajaran motivasi bahasa Arab dalam kalangan pelajar IPTA dari perspektif sorotan kajian. ASEAN Comparative Education Research Journal on Islam and Civilization (ACERJ), Volume 1(2) September 2017, 102-112.

Teh, K.S.M., Yusoff, N, N. M. R., Embi, M. A., \& Mahamod, Z. (2008). Hubungan gender dengan strategi pembelajaran bahasa Arab dalam kalangan pelajar sekolah menengah agama di Terengganu. Malaysian Journal of Learning \& Instruction, 5, 117-138.

Tu'imah, R. A. (1989). Ta'allum al-'Arabiyyat li ghayr al-nātiqīn bihā. Rabat, Maroko: ISESCO.

Waty, E. R. K. (2017). Penilaian kualiti ujian sumatif yang dibangunkan guru sekolah menengah atas di Palembang, Indonesia (Doctoral dissertation, Universiti Pendidikan Sultan Idris).

Wulansari, Z. (2015). Implementasi pendekatan ilmiah (scientific approach) dan penilaian otentik (authentic assessment) pada mata pelajaran Pendidikan Agama Islam dan Budi Pekerti di Kurikulum 2013 (Studi 


\section{\begin{tabular}{l|l}
\hline E-ISSN 2550-1992 & $\begin{array}{l}\text { Published biannually by: } \\
\text { Faculty of Islamic Civilization Studies, }\end{array}$
\end{tabular} \\ 4. - TrSt ad $\begin{aligned} & \text { Selangor International Islamic University College (KUIS) } \\ & \text { Bandar Seri Putra, 43600, Bangi, Selangor (Darul Ehsan) Malaysia. }\end{aligned}$

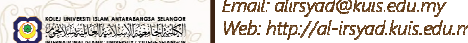 \\ JOURNAl Al-IRSYAd Vol. 5, No. 2, (December, 2020)}

kasus di SMK Telekomunikasi Tunas Harapan Tengaran Kab. Semarang dan SMK Negeri 1 Tengaran $K a b$. Semarang (Doctoral dissertation, IAIN Salatiga).

Yusoff, N. N. M. R. \& Ghani, A. K. (1999). Faktor-faktor yang mempengaruhi keberkesanan penguasaan kemahiran kefahaman bacaan bahasa Arab di kalangan pelajar-pelajar sekolah menengah agama: kajian di Negeri Kelantan. Bangi: Laporan Projek, Universiti Kebangsaan Malaysia. 